\title{
Urban micro-climate in the City of Mosul, Iraq (The Effect of Urban Space Characters on Air Temperature)
}

\author{
Turki Hassan Ali*. \\ Bahjat Rashad Shaheen** \\ *Department of Architecture- College of Engineering, Mosul University \\ **Department of Architecture- College of Engineering, Baghdad University
}

\begin{abstract}
The proportion of the world's population living in urban areas is constantly increasing. Different urban shapes result different micro-climates. The way cities are planned and build is therefore important for the global energy use. The city of Mosul ( north of Iraq) had witnessed a rapid urbanization during the second half of the last century, adopting the open grid iron system in planning the new residential areas which now exist beside the traditional compact system. This study present result from measurements of Max. air temperature during hot season in (156) points in the traditional paths of the old city (called zuqaqu) and (44) points in the streets of the modern neighborhoods, more over the engineering-physical characteristics of each point had been measured. Using statistical analyzing for determining the impact of each of these characters on the urban micro climate (Max. air temperature). The primary results show that sky view factor has the major impact on air temperature, and that confirm the important role of the urban designers and planners in the urban micro-climate. Key words: urban microclimate, traditional city, Mosul.
\end{abstract}

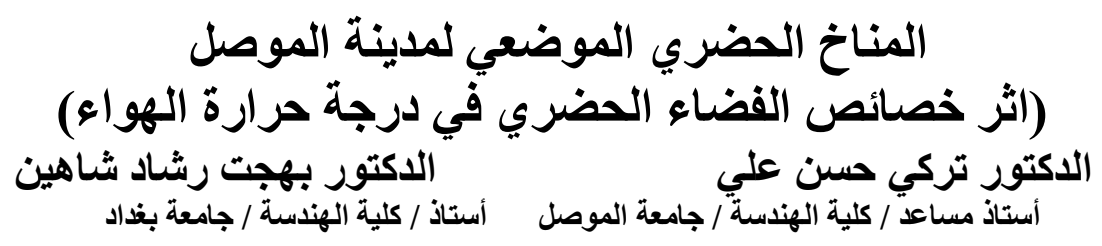

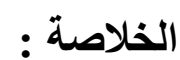

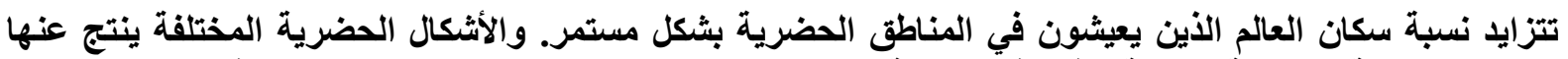

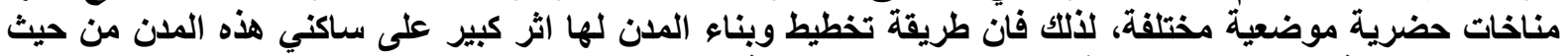

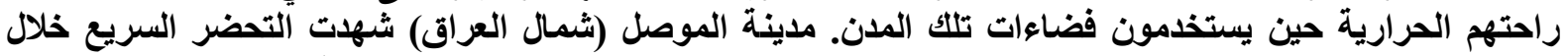

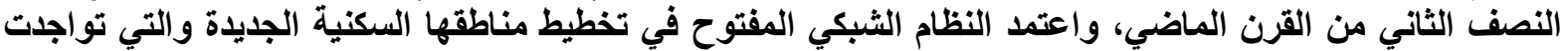

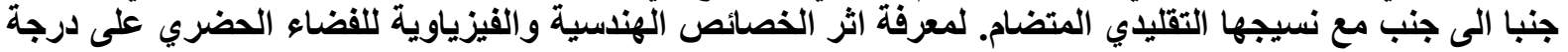

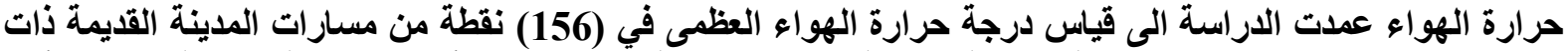

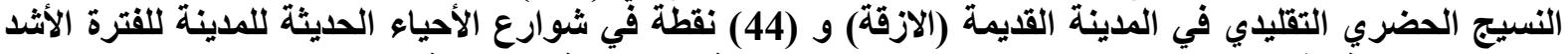

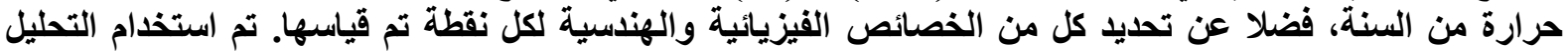

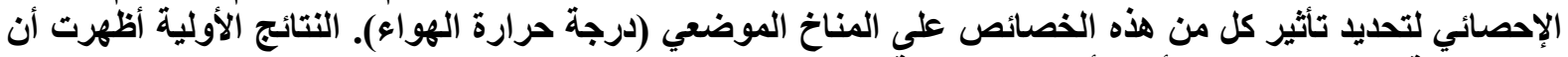

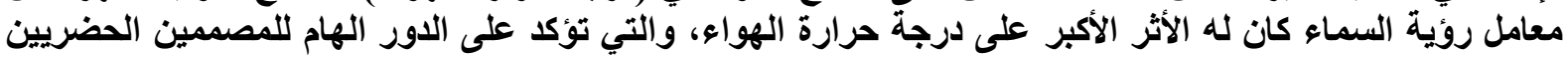

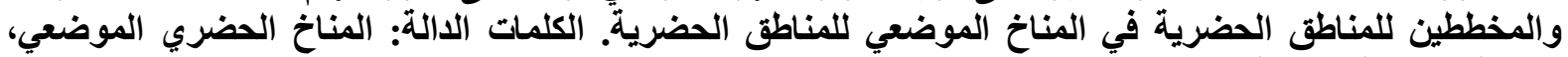
المدينة التقليدية ، مدينة الموصل. 


\section{1-Introduction}

The proportion of the world's population that lives in urban areas is constantly increasing. Urbanization gives rise to economic growth, which results in higher energy use for e g: cooling and heating buildings. The way cities are planned and built is therefore important for the global energy use, and for creating livable spaces for the individuals within the urban fabric. Most of the Arabic cities adopt the gridiron type (wide open streets) in their planning without any regard to the hot-dry climate consideration, which prevail in most of them.

This work aims at studying the degree of influence of the urban path physical-engineering characters on urban microclimate (AIR TEMPERATURE). Accordingly, we look at the relationship between the built space and environment, so it is assumed that variations of urban path configurations and characters cause significant climate modifications, and has significant impact on the thermal comfort of the individuals and energy use.

From this general hypothesis, fundamental question rises, is there any valid way making it possible to quantify the impact of these physical-engineering characters of urban path on the air temperature in the urban micro climate?

However, we do not dispute the already formalized links between urban form and the climate. They have been addressed in several studies [1], [2]. In the context of our work, we look for the precise interpretation of these links, by using a statistical analysis to evaluate the influence of urban path characters on the climatic factor (air temperature).

\section{2-Background}

Mosul, with almost two million inhabitants, is the third largest city in Iraq. Mosul is situated 36.19 N, 43.09 E, at $230 \mathrm{~m}$ above sea level in a hilly area between the Mountains in the North and the Al-jazeera plane in the South and the West, Tigress River divides the city into two parts. The climate of Mosul is characterized by hot and dry summers and cold winters with rare snow, [3]. Annual mean temperature is $\mathbf{1 9 . 5}$. $^{\mathrm{C}}$ and rainfall is $\mathbf{3 8 3} \mathrm{mm}$, [4]. Monthly climate data is shown in figure $(1,2)$.

Mosul consists of two contrasting parts: the traditional Arabic-Islamic, organic urban pattern, the old city, and the modern city with its gridiron urban pattern. Six housing neighborhoods in each part of the city were studied. The old city is one of the most densely developed areas. Introverted courtyard buildings in two to three stories surround the narrow streets, which cut deep ravines through the city. The street network is irregular. This means that the buildings shade each other, there is a great variation of traditional building elements and a large number of building details provide shade at street level.

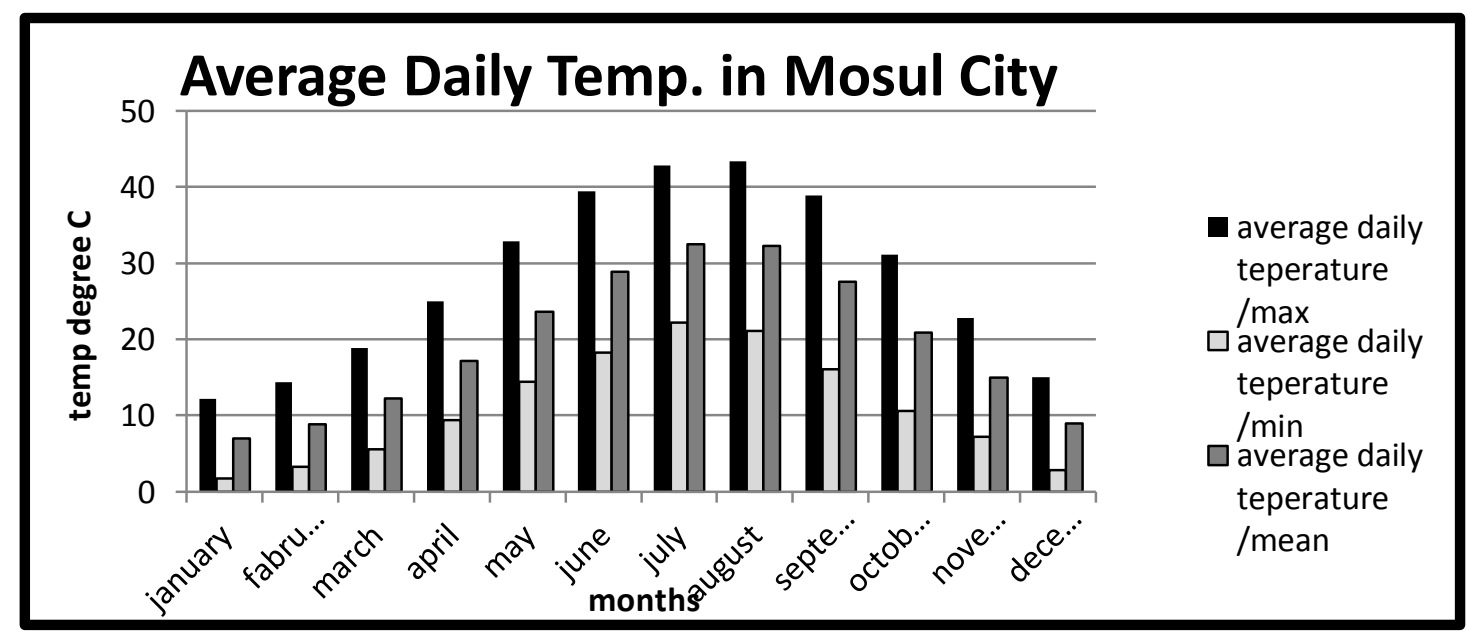

Figure (1) Max. \& Min air temperature in Mosul City. [4]. 


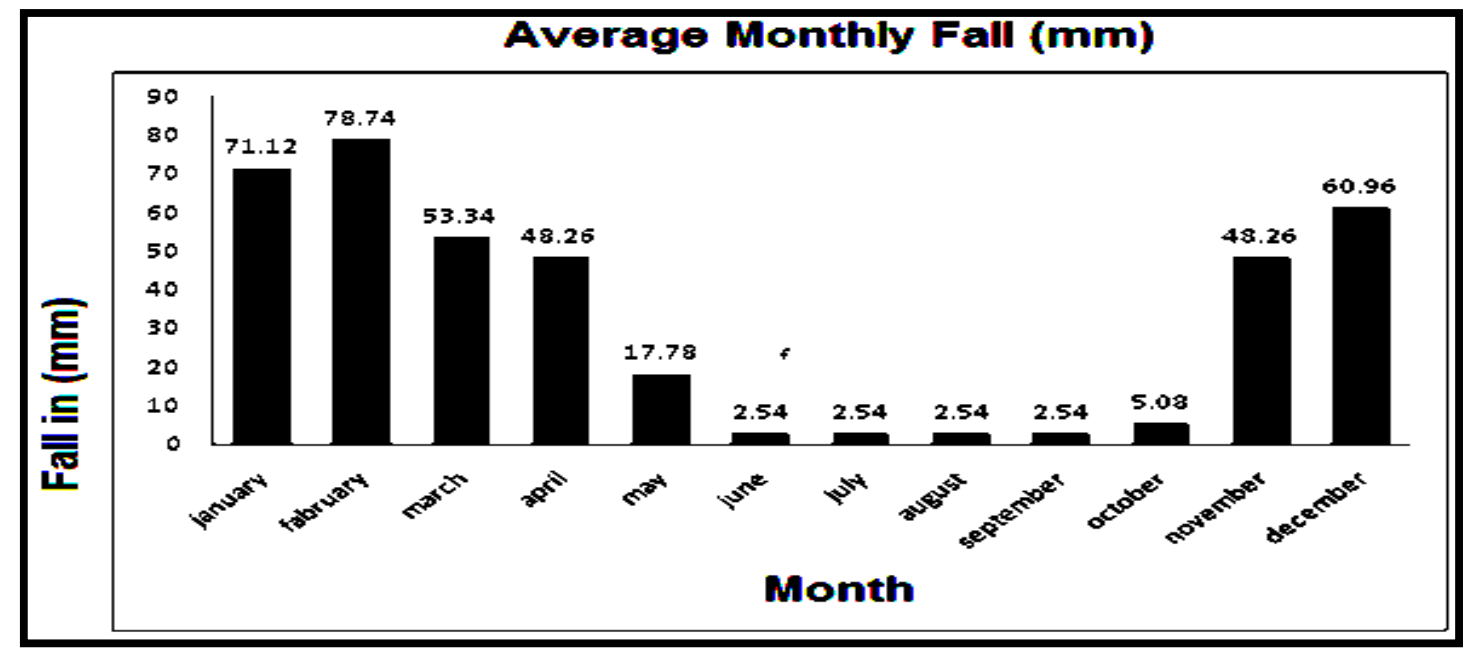

Figure (2) Monthly Rain Fall in Mosul City. [4].

\section{2-1-Problem}

Different urban shapes result in different urban micro-climates. This study seeks to define the relationship between urban space characters (physical-engineering factors) and urban microclimate (Max. temperature) in traditional and modern living areas of Mosul city. The aim is to quantify the effect of these factors so the urban designer can make use of this in their designs to enhance the quality of urban micro-climate, which reflect to the comfort level of users of the urban space and energy consumption.

\section{3-Methodology}

In the traditional neighborhoods (156) measuring points were studied, distributed at six neighborhoods (Great Mosque, Maidan, Bad Al-bath,Maiyassa, Makaoui and Khazrag), and (44) measuring points in the six modern neighborhoods ( Al-maliya, Al-Thubat, Summer, Al- suha, Al Muthana ana Domez), figure $(3,4)$. Measurements were made in different types of paths, (cul-de-sac, and open and covered paths). The streets had different orientations.

For each measuring point, Max air temperature (measured in the middle of the street canyon, $2 \mathrm{~m}$ above street level), physical characters (reflection coefficient of the ground and the walls material and color) and engineering characters (orientation, height to width (H/W) ratio, sky view factor) were measured. See table (1) and figure (5). The instrument was protected from sunlight during the measurements. The measurements took place at $2 \mathrm{am}$. The measurements were made in each neighborhood at one day, with other measurement took place at meteorological station synchronously. The Climate Measurements were made during summer, 20 July to 5 august in 2007, the non-urban climate for Mosul for the actual periods, measured at the meteorological situated on the outskirts of the city, Air temperature was measured with device called (testo-179-H2). The accuracy of the air temperature is $\pm 0.5^{\circ} \mathrm{C}$.

After defining the physical-engineering characters of each measuring point in the two set of the neighborhoods (traditional and modern), the research consider these characters as dependent factors, and the climatic factor as independent factor, as the following:

The dependent factors are:

$\mathrm{X} 1=$ type of urban fabric.

$\mathrm{X} 2=$ orientation of the path.

$\mathrm{X} 3=$ sky view factor, Figure (5) explain measuring method.

$\mathrm{X} 4=$ width to height ratio $(\mathrm{W} / \mathrm{H})$.

$\mathrm{X} 5=$ reflection factor of ground material. 
$\mathrm{X} 6=$ reflection factor of facades material.

$\mathrm{X} 7=$ reflection factor of facades color.

The independent factor is:

Y1= Max air temp. at measuring point- Max air temperature at meteorological Station.

To explore the relation between these factors the study used statistical program (SPSS), in order to make regression analysis, the effect of each physical-engineering factors on urban air temperature factor were determined.

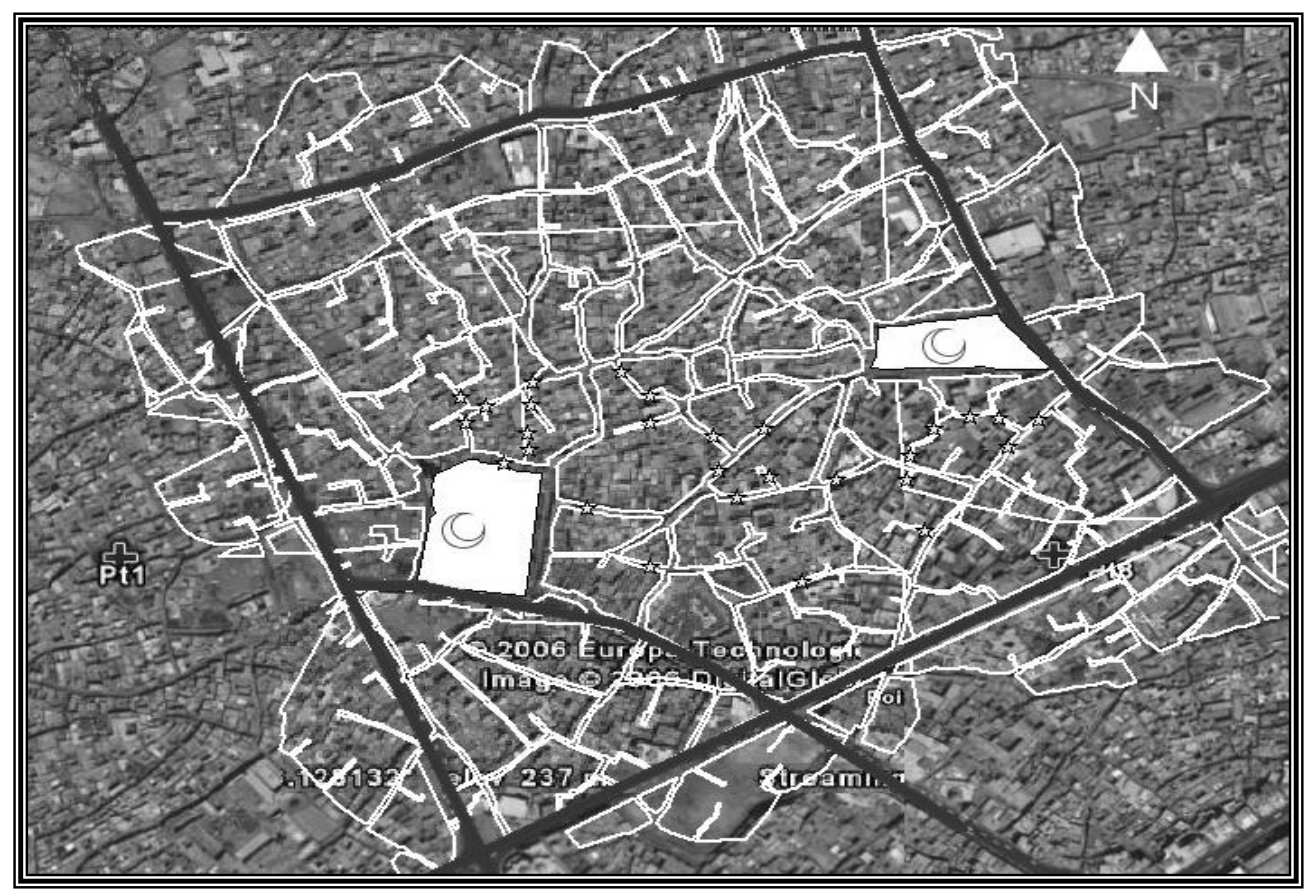

Figure (3) Measuring points at one of the Traditional neighborhoods - Great Mosque neighborhood at the Right Bank of Mosul- (*= exact location of measuring point) [4].

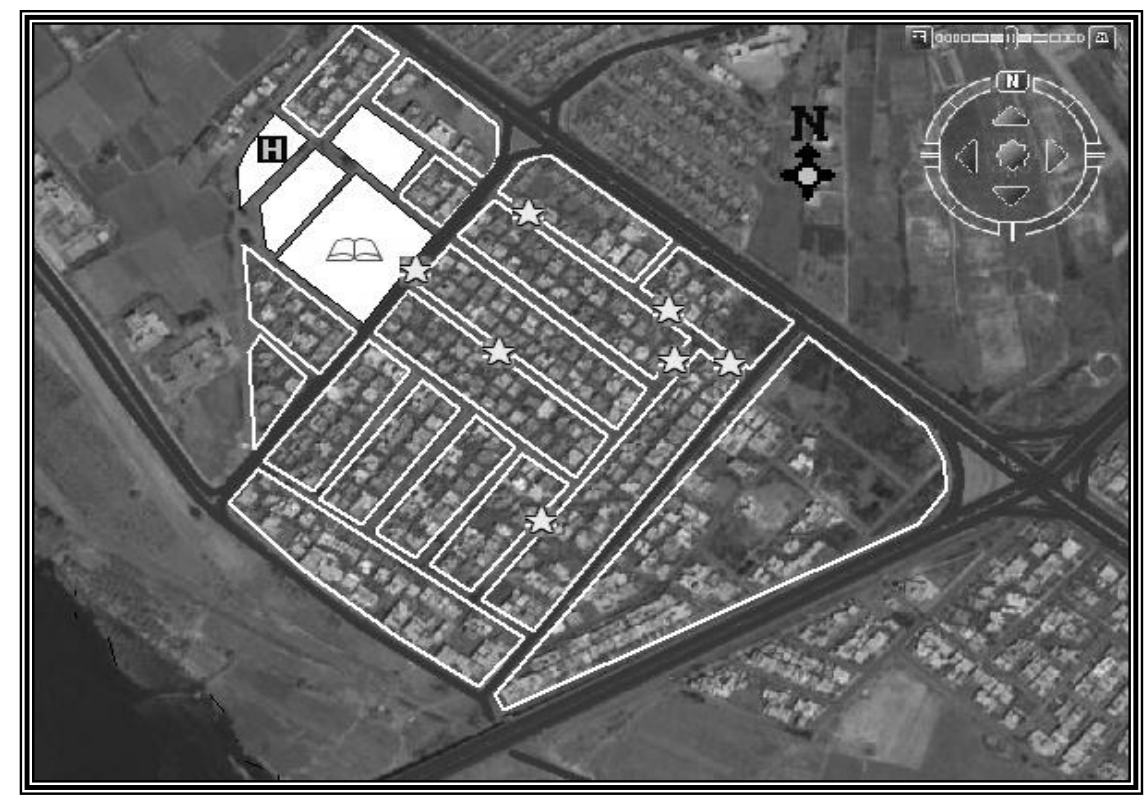

Figure (4) Measuring points at one of the Modern neighborhoods - Al-Thubat neighborhood at the Left Bank of Mosul - (*= exact location of measuring point) [4]. 


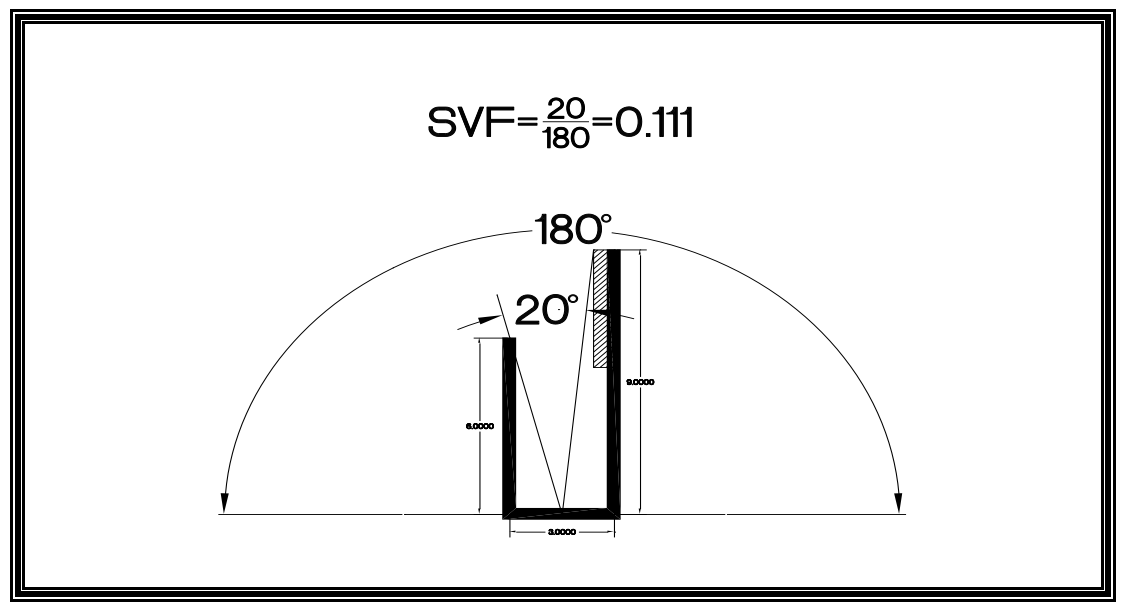

Figure (5) Measuring Method of sky view factor (SVF). [4].

Table (1) Sample of measuring points shows the data gathered through the field survey. [4]

\begin{tabular}{|c|c|c|c|c|c|c|c|c|c|c|c|c|c|c|c|c|c|c|c|c|}
\hline 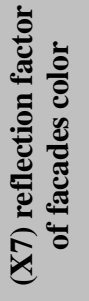 & 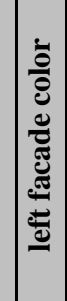 & 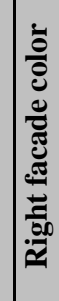 & 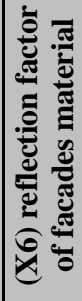 & 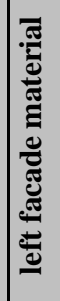 & 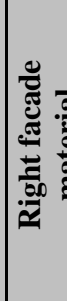 & 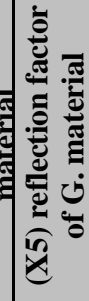 & 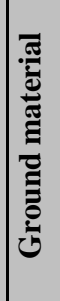 & & 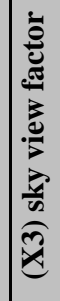 & 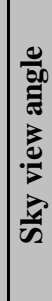 & 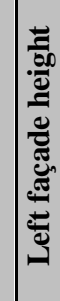 & 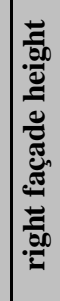 & 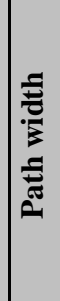 & 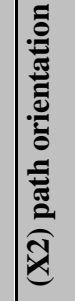 & 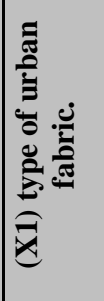 & 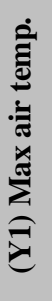 & 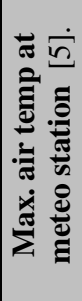 & 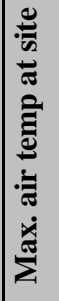 & 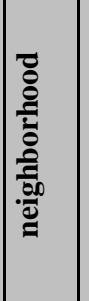 & $\dot{8}$ \\
\hline$\stackrel{+}{0}$ & 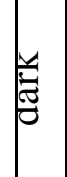 & 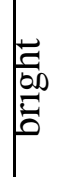 & $\ddot{0}$ & 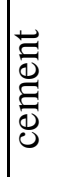 & 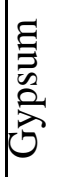 & 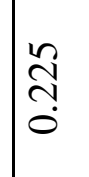 & 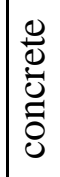 & \begin{tabular}{l}
$+\infty$ \\
\hdashline \\
\hdashline
\end{tabular} & $\frac{\infty}{\hat{n}}$ & in & 0 & $\vec{m}$ & 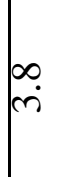 & $\begin{array}{l}3 \\
n_{1} \\
z \\
z\end{array}$ & 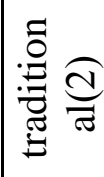 & $\begin{array}{l}0 \\
i \\
i\end{array}$ & $\stackrel{\sim}{\ddot{\gamma}}$ & Oீ. & $\mid \begin{array}{l}0 \\
0 \\
0 \\
\sum_{0} \\
ن\end{array}$ & \\
\hline$\hat{o}$ & $\begin{array}{l}\vec{E} \\
\vec{\infty} \\
\overrightarrow{0}\end{array}$ & & $\frac{n}{n}$ & 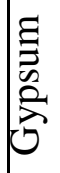 & 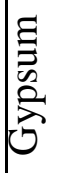 & ָ̃ & 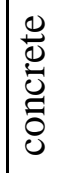 & $\begin{array}{l}m \\
m \\
m \\
m\end{array}$ & $\frac{\infty}{6}$ & \pm & $\cong$ & $\infty$ & $m$ & $\frac{1}{\sqrt{n}}$ & 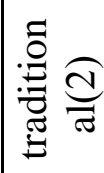 & $\underset{\sim}{\sim}$ & 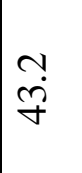 & 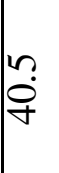 & $\left|\begin{array}{l}0 \\
0 \\
0 \\
\sum_{0} \\
ن\end{array}\right|$ & $N$ \\
\hline$\tilde{0}$ & $\begin{array}{l}\vec{E} \\
00 \\
\overrightarrow{0}\end{array}$ & & $\frac{n}{n}$ & 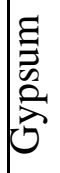 & 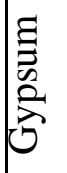 & ָ̃ & 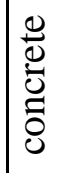 & $\frac{\approx}{\infty}$ & 占 & in & $m$ & $m$ & . & $\begin{array}{l}B \\
1 \\
-1\end{array}$ & 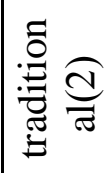 & $\hat{\sim}$ & $\stackrel{\sim}{\ddot{\gamma}}$ & ?n & $\mid \begin{array}{l}0 \\
0 \\
0 \\
\sum_{0} \\
ن\end{array}$ & $m$ \\
\hline$\tilde{0}$ & $\begin{array}{l}\vec{E} \\
00 \\
\overrightarrow{0} \\
\overrightarrow{0}\end{array}$ & & $\frac{n}{n}$ & 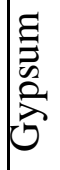 & 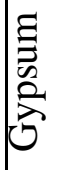 & 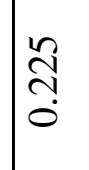 & 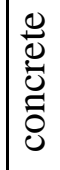 & $\frac{\approx}{\infty}$ & है. & N & $\cong$ & \pm & ب. & {$\left[\begin{array}{l}n_{1} \\
z_{1}\end{array}\right.$} & 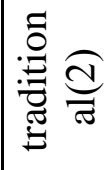 & $\frac{9}{i}$ & $\stackrel{\sim}{\ddot{\gamma}}$ & $\frac{n}{\nexists}$ & $\mid \begin{array}{c}0 \\
\sum_{0} \\
0 \\
0\end{array}$ & $\nabla$ \\
\hline$\tilde{0}$ & $\begin{array}{l}\vec{E} \\
00 \\
\overrightarrow{0}\end{array}$ & 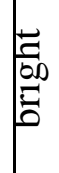 & $\frac{n}{n}$ & 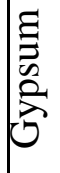 & 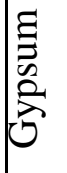 & ֶ̃ & 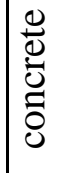 & م. & 6. & 0 & 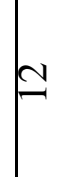 & $\underline{\underline{\theta}}$ & $m$ & $\begin{array}{l}3 \\
n_{2} \\
\text { z }\end{array}$ & 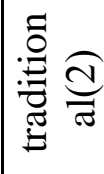 & $\vec{i}$ & $\stackrel{r}{\dddot{\gamma}}$ & 守 & $\mid \begin{array}{l}\vec{D} \\
\sum_{0}^{0} \\
0\end{array}$ & in \\
\hline$\stackrel{+}{0}$ & ש & $\begin{array}{l}\vec{Z} \\
\overrightarrow{000} \\
\vec{\Xi}\end{array}$ & 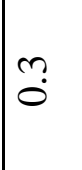 & 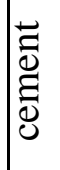 & 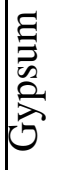 & 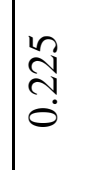 & 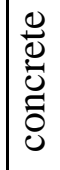 & $\stackrel{n}{n}$ & 象 & $n$ & $\infty$ & $r$ & $N$ & $\mid \begin{array}{l}n_{1} \\
z_{1}\end{array}$ & 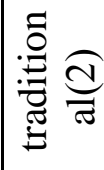 & $\stackrel{\nabla}{\sim}$ & $\stackrel{\sim}{\ddot{y}}$ & 我 & $\sum_{0}^{0}$ & 0 \\
\hline$\stackrel{+}{0}$ & $\bar{Z}$ & $\begin{array}{l}\vec{E} \\
\overrightarrow{000} \\
\bar{\Xi}\end{array}$ & 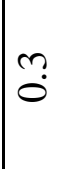 & 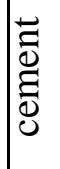 & 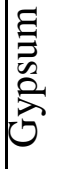 & તิ & 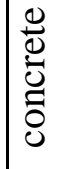 & $\underset{8}{8}$ & $E$ & $m$ & $r$ & 6 & $\because$ & $\mid \begin{array}{l}3 \\
1 \\
1\end{array}$ & 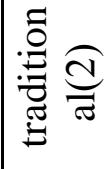 & ָָ & 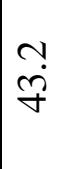 & $\nabla$ & $\sum_{\substack{0 \\
\infty \\
0}}^{0}$ & \\
\hline
\end{tabular}




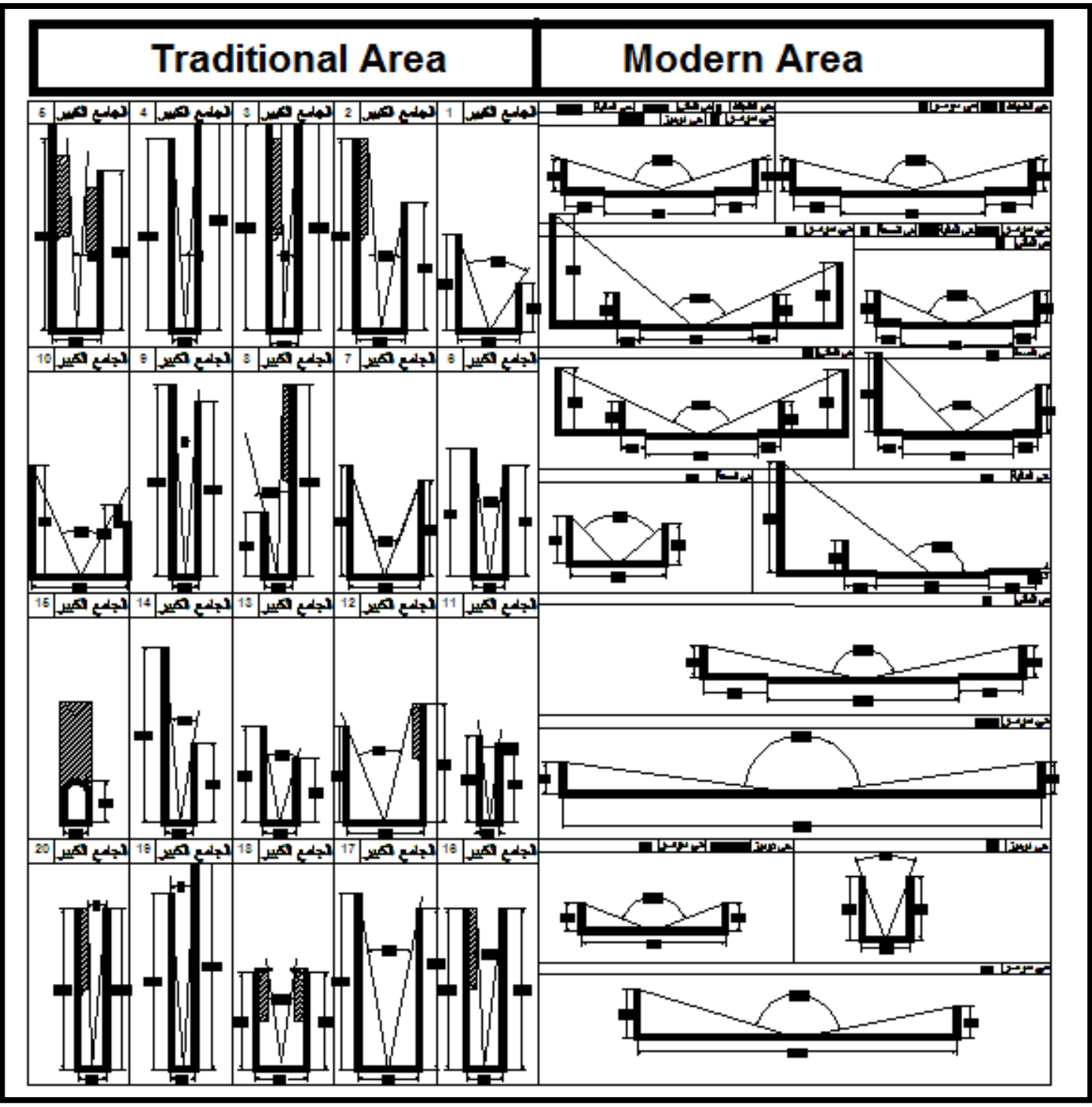

Figure (5) Sample of Sections through Measuring points at a Traditional and Modern neighborhoods. [4].

\section{4-Rsesults}

Table (1) shows that the summary of the field survey of the physical-engineering characters and Max air temperature of measuring points, we can notice the following:

1) The mean difference in Max. air temperature between measuring points in the traditional urban path and Meteorological Station was (-1.05) $\circ \mathrm{C}$, while the same indicator in the modern urban fabric measuring points was $(+2.11) \circ \mathrm{C}$. The lowest reading in the traditional fabric was $(-3.30) \circ \mathrm{C}$, while the in the modern fabric was $(0.1) \circ \mathrm{C}$, The highest reading in the traditional fabric was $(+0.6) \circ \mathrm{C}$, while the in the modern fabric was $(+7.3) \circ \mathrm{C}$

2) Standard deviations of reading in the traditional fabric is the lower than the reading in the modern fabric.

3) The average width of urban path in the traditional fabric was (3) meters, while the average width of the modern street was (12) meters. The average height of the traditional facades was (6.5) $\mathrm{m}$ and (2) $\mathrm{m}$ for the modern facades.

4) Mean Sky view factor (SVF) for the traditional spaces was (0.14), and (0.77) for the modern spaces. 
The regression analysis shows a significant relation $(\mathrm{p}<0.001)$ between Max. air temperature factor and the combination of the physical-engineering factors, where the correlation coefficient reach (0.75), see table (2) . Thus the equation which governing this relation is:

\section{$\mathrm{Y} 1=1.69-0.28(\mathrm{X} 1)+0.00035(\mathrm{X} 2)+2.56(\mathrm{X3})-0.05(\mathrm{X} 4)-11.72$ (X5) $-2.84(\mathrm{X6})+1.85(\mathrm{X} 7)$}

Noticing the effect of each factor individually, the sky view factor $(0.38)$ has the major effect followed by ground material factor $(-0.27)$ then finally the facades color factor $(0.14)$.

Table (2) Regression analysis result

\begin{tabular}{||l|l|l|l|l||}
\hline \hline Dependant variables & coefficient & $\begin{array}{l}\text { Standard } \\
\text { coefficient }\end{array}$ & t value & $\mathrm{p}$ value \\
\hline $\mathrm{X} 1=$ type of urban fabric. & -0.28 & -0.07 & -0.4 & 0.69 \\
\hline $\mathrm{X} 2=$ orientation of the path. & 0.00035 & 0.01 & 0.18 & 0.86 \\
\hline $\mathrm{X} 3=$ sky view factor. & 2.56 & 0.38 & 2.2 & 0.029 \\
\hline $\begin{array}{l}\mathrm{X} 4=\text { width to height } \\
\text { ratio (W/H). }\end{array}$ & -0.05 & -0.04 & -0.61 & 0.54 \\
\hline $\begin{array}{l}\mathrm{X} 5=\text { reflection factor of } \\
\text { G. material. }\end{array}$ & -11.72 & -0.27 & -4.28 & $<0.001$ \\
\hline $\begin{array}{l}\mathrm{X} 6=\text { reflection factor of } \\
\text { facades material. }\end{array}$ & -2.84 & -0.10 & -1.06 & 0.29 \\
\hline $\begin{array}{l}\mathrm{X} 7=\text { reflection factor of } \\
\text { facades color. }\end{array}$ & 1.85 & 0.14 & 2.65 & 0.009 \\
\hline Equation constant & 1.69 & - & 1 & 0.32 \\
\hline \hline
\end{tabular}

$r$ value $=0.75(p<0.001) \cdot p<0.05=$ significant

\section{5-Conclusion}

1) Sky view factor have the major effect in air temperature of the urban micro climate, this mean that the role of engineering characteristics are more important than the role of the physical characteristics of urban space. That means the important role played by urban designer in this regard. Through Planting trees in street medians petition and sidewalk, the use of the covered corridors by cantilevers and other architectural means.

2) The measurements indicate the differences in the Max. air temperature between the compact urban fabric in the old city and the very open urban fabric of modern neighborhoods. In the densest part, of the old city the air temperature is normally lower than the non-urban temperature at the meteorological station, whereas it is higher in modern neighborhood streets. One explanation to this is that the sun does not penetrate down into the narrow street canyons.

3) The factor of urban path orientation has no effect in air temperature of the urban microclimate, because the air temperature was measured in the shade.

4) Legislate planning laws and regulations for those who are concerned with domain of city planning and design, in order to achieve good urban climate performance of its urban spaces, and achieving sustainable city concept. The research proposes a review to setback law in residential areas to get a smaller sky view factor. By allowing people to build in the front part of the land at the ground floor level, and have the possibility of building over street space on the upper floors at certain places. 
5) The study recommends that the ratio of width/ height of street space at residential areas no less than $(1: 2)$.

6) The (SVF) coefficient is no more than (16\%).

7) To achieve these two indices and satisfy the requirements of vehicle passing the study proposes canceling the setback distance (front garden), and allowing the construction at the front part of residential lots, and to have first floor cantilever and bridges over street space. That generates a corridor which will protect pedestrians from the solar radiation and precipitation, and reduce the heat load over buildings.

8) For existing residential areas, the study recommends to use the landscaping treatments, as planting evergreen trees on the sidewalk of local roads to achieve sky view coefficient. See Figure (6)

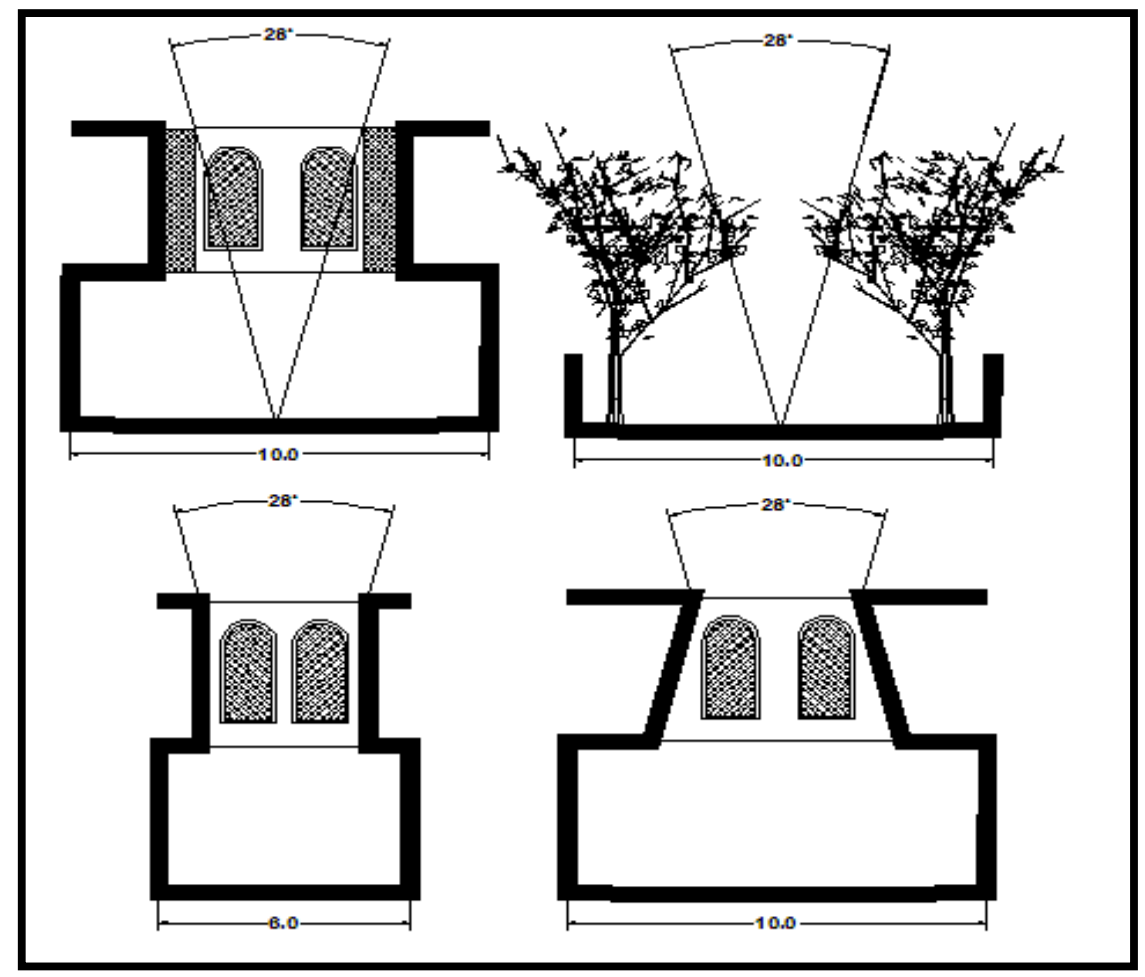

Figure (6): Proposed Sections for modern streets to enhance its micro-climate

\section{References:}

1- AIT-AMEUR, K. 2000. Exploring morphological indicators for studying the relationship between microclimate and urban form. Proceedings of PLEA 2000, Cambridge, UK. James \& James (Science Publishers) Ltd, PP535-536.

2- ROSENLUD, H. et al, 2000. Urban micro-climate in the City of Fez, Morocco. Proceedings of PLEA 2000, Cambridge, UK. James \& James (Science Publishers) Ltd, PP472-476.

3- Aljanabi, S., 1991. Mosul Geography: a study in the regional relations. Civil Mosul Encyclopedia, vol. 1, Book House Publication, University of Mosul, Iraq P 13.

4- Ali, Turki H., 2007. Environmental Reference in the Traditional Arabic city. Ph.D. thesis, College of Engineering-University of Baghdad, Iraq, PP 46-49.

5- Meteorological data for the city of Mosul.

The work was carried out at the college of Engineering. University of Mosul 